\title{
Salt shell fallout during the ash eruption at the Nakadake crater, Aso volcano, Japan: evidence of an underground hydrothermal system surrounding the erupting vent
}

\author{
Hiroshi Shinohara ${ }^{1^{*}} \mathbb{D}$, Nobuo Geshi ${ }^{1}$, Akihiko Yokoo ${ }^{2}$, Takahiro Ohkura ${ }^{2}$ and Akihiko Terada ${ }^{3}$
}

\begin{abstract}
A hot and acid crater lake is located in the Nakadake crater, Aso volcano, Japan. The volume of water in the lake decreases with increasing activity, drying out prior to the magmatic eruptions. Salt-rich materials of various shapes were observed, falling from the volcanic plume during the active periods. In May 2011, salt flakes fell from the gas plume emitted from an intense fumarole when the acid crater lake was almost dry. The chemical composition of these salt flakes was similar to those of the salts formed by the drying of the crater lake waters, suggesting that they originated from the crater lake water. The salt flakes are likely formed by the drying up of the crater lake water droplets sprayed into the plume by the fumarolic gas jet. In late 2014, the crater lake dried completely, followed by the magmatic eruptions with continuous ash eruptions and intermittent Strombolian explosions. Spherical hollow salt shells were observed on several occasions during and shortly after the weak ash eruptions. The chemical composition of the salt shells was similar to the salts formed by the drying of the crater lake water. The hollow structure of the shells suggests that they were formed by the heating of hydrothermal solution droplets suspended by a mixed stream of gas and ash in the plume. The salt shells suggest the existence of a hydrothermal system beneath the crater floor, even during the course of magmatic eruptions. Instability of the magmatic-hydrothermal interface can cause phreatomagmatic explosions, which often occur at the end of the eruptive phase of this volcano.
\end{abstract}

Keywords: Aso volcano, Hydrothermal system, Salt, Fallouts, Ash leachate, Volcanic eruption

\section{Introduction}

Volcanic lakes are efficient traps for volcanic volatiles and heat supplied from depth. The composition, temperature, or volume of water in the lakes are considered as indicators of the mass and energy budget of the magmatic-hydrothermal system (e.g., Delmelle and Bernard 2000; Pasternack and Varekamp 1997; Terada and Hashimoto 2017). Various types of eruptions occur at volcanic lakes, ranging from phreatic to magmatic. The eruptions at volcanic lakes are often associated with changes in

\footnotetext{
*Correspondence: shinohara-h@aist.go.jp

${ }^{1}$ Geological Survey of Japan, National Institute of Advanced Industrial Science and Technology, Central 7, 1-1-1 Higashi, Tsukuba, Ibaraki 305-8567, Japan

Full list of author information is available at the end of the article
}

the balance of the magmatic-hydrothermal interactions (Rouwet and Morrissey 2015). Geochemical monitoring has revealed the nature and variation in the magmatichydrothermal interactions (e.g., Christenson et al. 2010; Rouwet et al. 2014).

The Nakadake cone of the Aso volcano, Japan, hosts a hot and acid crater lake and is one of the most active volcanoes in the country, with frequent phreatic to magmatic eruptions. The high levels of temperature and acidity indicate a large volcanic gas flux into the crater lake. Energy and material budget modeling of the crater lake revealed that more than half of the water in the lake is supplied through high-temperature volcanic fluids, and that more than half of the water is also lost by evaporation (Terada et al. 2012). Variation in volcanic activity has been observed with associated changes in the crater 
lake activity (Kawakatsu et al. 2000; Sudo et al. 2006). During the quiet period, the crater is filled by the lake water. With a decrease in the lake's water level, intermittent small phreatic eruptions begin to occur. After the lake has dried completely, high-temperature gas vents appear at the bottom of the crater, which then start to emit volcanic ashes. With a widening of the vent, the ash eruptions become continuous and intense and become associated with intermittent Strombolian activity. The crater lake waters recover with weakening the activity of magmatic eruptions. Phreatic-phreatomagmatic explosions often occur during and at the end of the eruption cycle (Ono et al. 1995; Sudo et al. 2006). Similar variations in volcanic activity and the surface manifestation of the crater lakes are observed in other volcanoes (Martínez et al. 2000; Rouwet and Morrissey 2015). The magmatic-hydrothermal interactions may control the correlation between the crater lake variations and the eruption cycle. However, the nature of the hydrothermal system during the absence of the crater lake is poorly known.

Recently, fallouts of salt-rich materials from the volcanic plume were observed during a high activity of the Nakadake crater, including during ash eruptions. We collected a few different types of the salt fallouts and report their occurrence, textural features and chemical compositions. The composition of the ash leachates and crater lake waters was also analyzed to compare with those of the salt fallouts. The origin of the salt fallouts precipitated during a period of crater lake absence is discussed, to understand the magmatic-hydrothermal interaction beneath the crater floor.

\section{Aso volcano}

The Aso volcano is one of the largest caldera volcanoes in the world, with the size of $25 \mathrm{~km}$ north-south and $18 \mathrm{~km}$ east-west diameter, and repeated gigantic pyroclastic flow eruptions from 270 to $90 \mathrm{ka}$. Several postcaldera cones, with compositions ranging from basalt to rhyolites, formed near the center of caldera after the last caldera-forming eruption (Ono and Watanabe 1985). The Nakadake cone is a stratocone with compositions ranging from basalt to basaltic-andesite and is the only active cone of the Aso volcano. During the past 6000 years, the dominant eruptive products at the Nakadake cone are black ash with some scoria, indicating that the foremost eruption style was that of continuous ash emission, that is called "ash eruption" (Ono et al. 1995). The Nakadake cone is currently quite active with repeated ash eruptions in 1974, 1979, 1984-1985, 1985-1995 and 2014-2015 (Ikebe et al. 2008; Ono et al. 1995; Yokoo and Miyabuchi 2015).
Another feature of the volcano is the hot and acid crater lake, located within the summit crater of the Nakadake cone. The crater lake is one of the hottest and most acidic crater lakes in the world, with water temperatures ranging from 40 to $80{ }^{\circ} \mathrm{C}$ and a $\mathrm{pH}$ level between -1 and +1 (Ohsawa et al. 2003, 2010; Miyabuchi and Terada 2009). The crater lake water submerges the crater bottom during a quiet period, and the water level decreases with an increase in the volcanic activity (Kawakatsu et al. 2000; Sudo et al. 2006). The bottom of Nakadake crater was filled with the crater lake water until 2009 (Shinohara et al. 2015), and the water volume decreased to almost zero in late 2011, when a few small phreatic eruptions occurred. The water volume recovered in 2012 and then decreased again to almost zero in late 2013 following several small phreatic eruptions. The crater bottom became hotter, and the incandescence was observed even in the daylight on November 18, 2014. The eruption started from the high-temperature vent on November 25, becoming more intensive with the enlargement of the vent (Yokoo and Miyabuchi. 2015). The eruption style was the continuous ash eruption with sporadic Strombolian activity, similar to past eruptions. The ash eruption culminated in late January, discharging $\sim 2 \times 10^{6}$ tons of ash until February 2, 2015 (Yokoo and Miyabuchi 2015; Marumoto et al. 2017). The eruption continued with some temporal pauses until May 21, 2015.

\section{Observation of fallouts}

Various non-silicate (salt) fallouts were observed at the Aso volcano during periods when the crater lake had almost or completely disappeared. The salt fallouts were first identified in May 2011, when the crater lake had almost dried out and a brownish plume emitted from a high-temperature vent of $585{ }^{\circ} \mathrm{C}$ at the center of the crater bottom. A small amount of water remained, surrounding the high-temperature vent (Fig. 1a). The saltrich materials of a flaky shape fell from the plume and were deposited on the flank. The fallouts are yellowishgray flakes, several $\mathrm{mm}$ in width, hereafter referred to as "salt flakes" (Fig. 1b). Salt flakes are fragile and are for the most part water-soluble. The brownish color of the plume is likely induced by the salt flakes. The salt flakes were observed on May 18, 19, and 31, 2011, and June 6 , of the same year by people visiting the crater rim on the leeward side of the plume. Although the fallouts were observed only on limited occasions, the salt flakes are likely released for 2 weeks since the emission of the brownish plume was continuously observed from midMay to early June. Eruptions and significant ash falls were not observed during this period. 

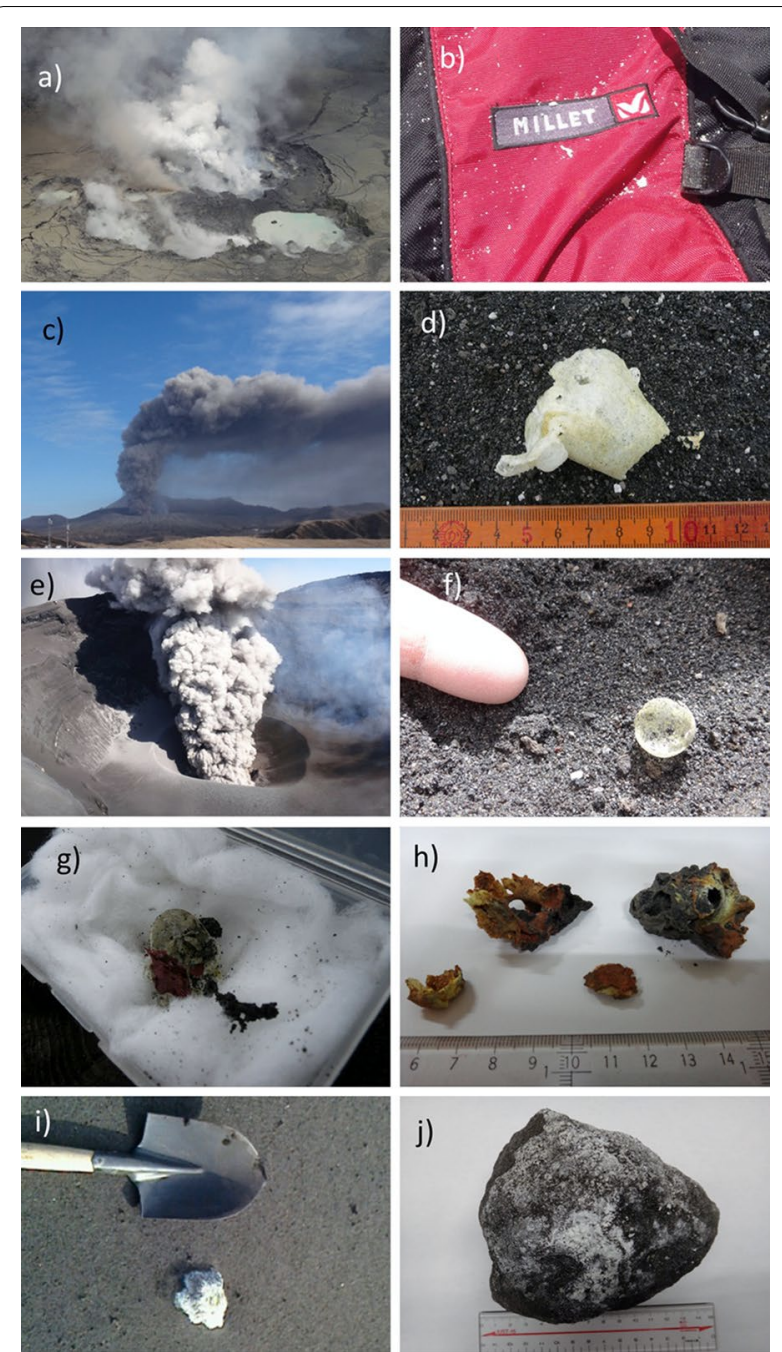

Fig. 1 Photographs of the activities and salt fallouts. a The crater bottom on May 19, 2011. The crater lake is almost dried out, presenting a brownish plume emitted from a high-temperature vent at the center of the crater bottom. Several other vents also emitted gases intensively. Small amounts of crater lake water remained around the vents. b The salt flakes settled on a backpack on May 19, 2011, at the leeward side of the plume toward the northern rim of the crater. c Ash eruption on January 13, 2015. d A salt shell observed on the ground on January 13, 2015. e The ash eruption on March 17, 2015. f A salt shell fallen from the gas plume $1 \mathrm{~h}$ after the temporal cessation of the ash eruption on March 17, 2015. g The salt shells collected on March 17, 2015, and stored in a box. The salts seem to be partly dissolved due to atmospheric moisture and partly recrystallized. $\mathbf{h}$ The salt lumps collected on March 26, 2015. i A bomb covered in fine white salts, found on December 27, 2014. j A close-up of the bomb in the laboratory. Most of the salts were fell off during transport because the salts are very fragile

The salt fallouts of different shapes were observed several times during the eruptive period of 2014-2015. The salts were discharged with the ashes during an ash eruption on January 13, 2015 (Fig. 1c). The salt fallouts had a hollow yellowish-white-colored shell structure, with a maximum size of $\sim 5 \mathrm{~cm}$, hereafter referred to as "salt shell" (Fig. 1d). The shells were thin and fragile, commonly occurring round, elongated, or coalesced round shapes. On March 17 and 20, 2015, the salts were released from the gas plume approximately $1 \mathrm{~h}$ after the temporal cease of the weak ash eruption (Fig. 1e). These fallouts were hollow, fragile, spherical shells of a yellowish-white color, with a maximum size of $\sim 1 \mathrm{~cm}$ (Fig. 1f). The shape and color of these salt shells were quite similar to the hollow sulfur spherules observed at several acid crater lakes such as Kusatsu-Shirane and Poás volcanoes (Ohashi 1919; Oppenheimer and Stevenson 1989; Takano et al. 1994). These salt shells, however, were for most part water-soluble and not sulfur spherules. They absorb moisture and were recrystallized into a denser structure after being stored in a box that was not sealed against the moisture (Fig. 1g). On March 26, 2015, similar dense salt materials (hereafter referred to as "salt lump"), a few $\mathrm{cm}$ in size, were found on the ground (Fig. 1h). These salt lumps look similar to the recrystallized salt shells. A volcanic bomb covered with salts of a white color (hereafter referred to as "white salt") was found on the eastern flank, $\sim 300 \mathrm{~m}$ from the vent, on December 27, 2014, after the occurrence of Strombolian activities (Fig. 1i). The salts covering the bomb were a layer of fine fibers, of a few $\mathrm{mm}$ in length (Fig. 1j). The bomb appeared porous and consisted of consolidated tuff without signs of a significant hydrothermal alteration. The bomb is less likely the product of the Strombolian activity, as it is likely to be a block of the non-juvenile lithics beneath the crater floor, which was ejected by the associated explosions. A bomb with the white salts was only found on this occasion.

\section{Analytical method}

All the salt materials, including the salt flakes, the salt shells, the salt lumps, and the white salts, were analyzed. In order to evaluate the origin of the salt materials, the composition of the crater lake waters and leachate of the ashes emitted by the ash eruptions was also analyzed. The water-soluble components were analyzed using ion chromatography, and the bulk composition was measured through energy-dispersive X-ray spectrometry (EDS). For the analyses of the water-soluble components, the salt materials were dissolved in pure water and filtered through a $0.45-\mu \mathrm{m}$ membrane filter, diluted, and analyzed without any further pre-treatment. Some solid materials, such as mineral and rock fragments, and elemental sulfur, remained settled after dissolution in the pure water. The concentrations of $\mathrm{F}, \mathrm{Cl}, \mathrm{SO}_{4}, \mathrm{Na}, \mathrm{K}, \mathrm{Mg}$, and $\mathrm{Ca}$ were determined. Fluoride forms complex chemical compounds under conditions of high Fe and Al content; therefore, the results of the $\mathrm{F}$ analyses of the crater 
lake waters by the ion chromatography are not accurate (Takano et al. 2000). An EDS (Oxford X-Max 20) on a scanning electron microscope (JEOL JSM6610LV) was used for the chemical composition analysis on the surface of the salt grains. Fragments of the salt samples were attached to an aluminum plate with double-side carbon tape and were then coated by graphite. Because the salt sample cannot be polished, only flat and smooth surfaces that could be oriented perpendicular to the microprobe were selected for analysis. The acceleration voltage of the electron microprobe was $15 \mathrm{kV}$, and the probe current was $\sim 1 \mathrm{nA}$. The X-ray signal lower than $10 \mathrm{keV}$ was analyzed.

Crater lake water samples were collected using the same method employed by Miyabuchi and Terada (2009). Chemical analyses of the lake water samples were performed by the Chikyu Kagaku Kenkyusho Co., Ltd (Nagoya, Japan). Concentrations of $\mathrm{F}, \mathrm{Cl}$, and $\mathrm{SO}_{4}$ were determined using ion chromatography, $\mathrm{SiO}_{2}$ was analyzed through a molecular absorption spectrometry method, and the cation concentrations were measured by an atomic absorption spectroscopy technique. The crater lake waters are very acidic, and some components, such as $\mathrm{HCl}$, are likely lost through evaporation (Shinohara et al. 2015; Capaccioni et al. 2016). In order to examine the effect of the evaporation, the crater lake water was dried overnight at $90^{\circ} \mathrm{C}$, and the dried material was then dissolved in pure water and analyzed using the same ion chromatography method as was used for the salt materials.

Water-soluble components of the volcanic ashes emitted in 2014-2015 were analyzed. The ashes, collected shortly after the deposition on a clean surface, were used for the analyses. These ashes were mixed with pure water by $1: 50$ weight ratio and agitated for about $60 \mathrm{~min}$ at a temperature of $\sim 40{ }^{\circ} \mathrm{C}$ in an ultrasonic bath, shaken intermittently. The solution was filtered using a 0.45 $\mu \mathrm{m}$ membrane filter after decantation and analyzed for the anions and cations using the ion chromatography method (Witham et al. 2005).

\section{Results}

The crater lake of the Aso volcano is a hyper-saline acid crater lake, and its composition varies with the lake volume, temperature, and volcanic activity (Ohsawa et al. 2003, 2010; Terada et al. 2012). Absolute concentrations of the dissolved species are variable. During 2008-2012, the measured sulfate concentration in the lake water varied between 40,000 and 130,000 ppm (Table 1). In contrast, the relative concentrations of the dissolved species were fairly constant (Fig. 2a). Concentrations of $\mathrm{SiO}_{2}$ and $\mathrm{Ca}$ are variable, likely due to the precipitation of gypsum and silica, which is a common process in hyper-saline lake waters (Varekamp et al. 2000). The composition of the dried crater lake water samples was almost identical to their original lake water compositions, except for low $\mathrm{Cl}$ contents. This likely indicates that the evaporation only removes the $\mathrm{HCl}$, whereas other anions, such as $\mathrm{F}$ and $\mathrm{S}$, remain as salts. Ashes contain quite variable amounts of water-soluble materials; e.g., the $\mathrm{SO}_{4}$ concentrations range from 400 to $110,000 \mathrm{ppm}$ (Table 1). Compositions of the ash leachate are variable, but have large $\mathrm{SO}_{4} / \mathrm{Cl}$ and $\mathrm{Na} / \mathrm{K}$ ratios, similar to the dried crater lake water samples (Table 1 and Fig. 2b). In contrast, the ash leachates have distinctly different composition than the crater lake waters and their dried samples, with larger $\mathrm{Ca} / \mathrm{Na}$ and smaller $\mathrm{Mg} / \mathrm{Na}$ ratios. The higher $\mathrm{Ca}$ concentrations are accompanied by a high $\mathrm{SO}_{4}$ concentration, with the $\mathrm{Ca} / \mathrm{SO}_{4}$ molar ratio being approximately one. This agrees with the common feature in ash leachates where a majority of the salt on ashes likely presents as $\mathrm{CaSO}_{4}$ and $\mathrm{NaCl}$ (Witham et al. 2005).

The dissolved salt fallouts analyzed by ion chromatography are rich in $\mathrm{F}, \mathrm{Cl}, \mathrm{SO}_{4}, \mathrm{Na}$, and $\mathrm{Mg}$, with an exception of the white salt, which is almost pure $\mathrm{NaCl}$ (Table 1 and Fig. 2c). Compositions of the dissolved salt flakes, shells and lumps are similar to those of the dried lake water samples, with large $\mathrm{Mg} / \mathrm{Na}$ ratios (close to one), and variable but small $\mathrm{Ca} / \mathrm{Na}$ ratios (smaller than one). The salt flakes emitted in 2011 have almost identical composition to the dried lake water samples. The salt shells and lumps emitted during the eruptive stage in 2015 have smaller $\mathrm{SO}_{4} / \mathrm{Na}$ and $\mathrm{Ca} / \mathrm{Na}$ ratios and larger $\mathrm{Cl} / \mathrm{Na}$ ratios than those of the salt flakes. The salt shells and lumps have similar composition. The compositions of the salt fallouts, as measured by the EDS analysis, are quite variable even when different spots on the same sample were analyzed. A $10 \times 10 \mu \mathrm{m}$ area is analyzed using the EDS, and the large observed variation indicates a heterogeneous composition, likely due to the distribution of nonwater-soluble particles such as fragments of mineral and rock fragments.

\section{Discussion}

Emission of water-soluble salts from volcanoes is not rare. Volcanic ashes commonly contain water-soluble salts (ash leachates) with variable contents (Witham et al. 2005). Water-soluble salts, such as $\mathrm{NaCl}$ and $\mathrm{KCl}$, are often found in the high-temperature fumarolic sublimates (Symonds 1993; Africano et al. 2002). However, the observation of the salt fallouts from a plume is an uncommon phenomenon, particularly from an ash plume. This study is the first report of such a case, as far as the authors know. Compositions of the salt fallouts, with the exception of white salt, are similar to the dried lake water samples, indicating the salt fallouts formation 


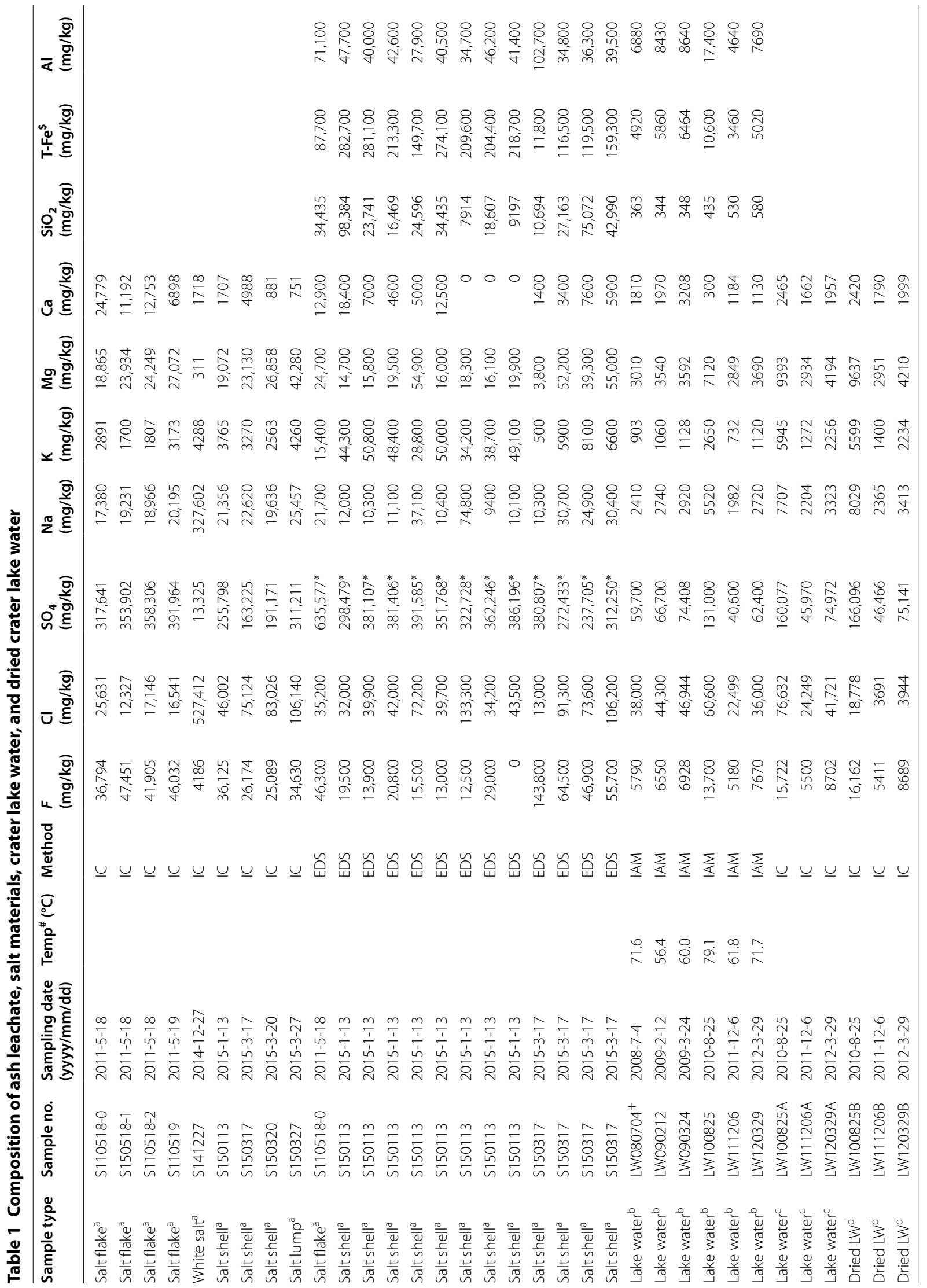




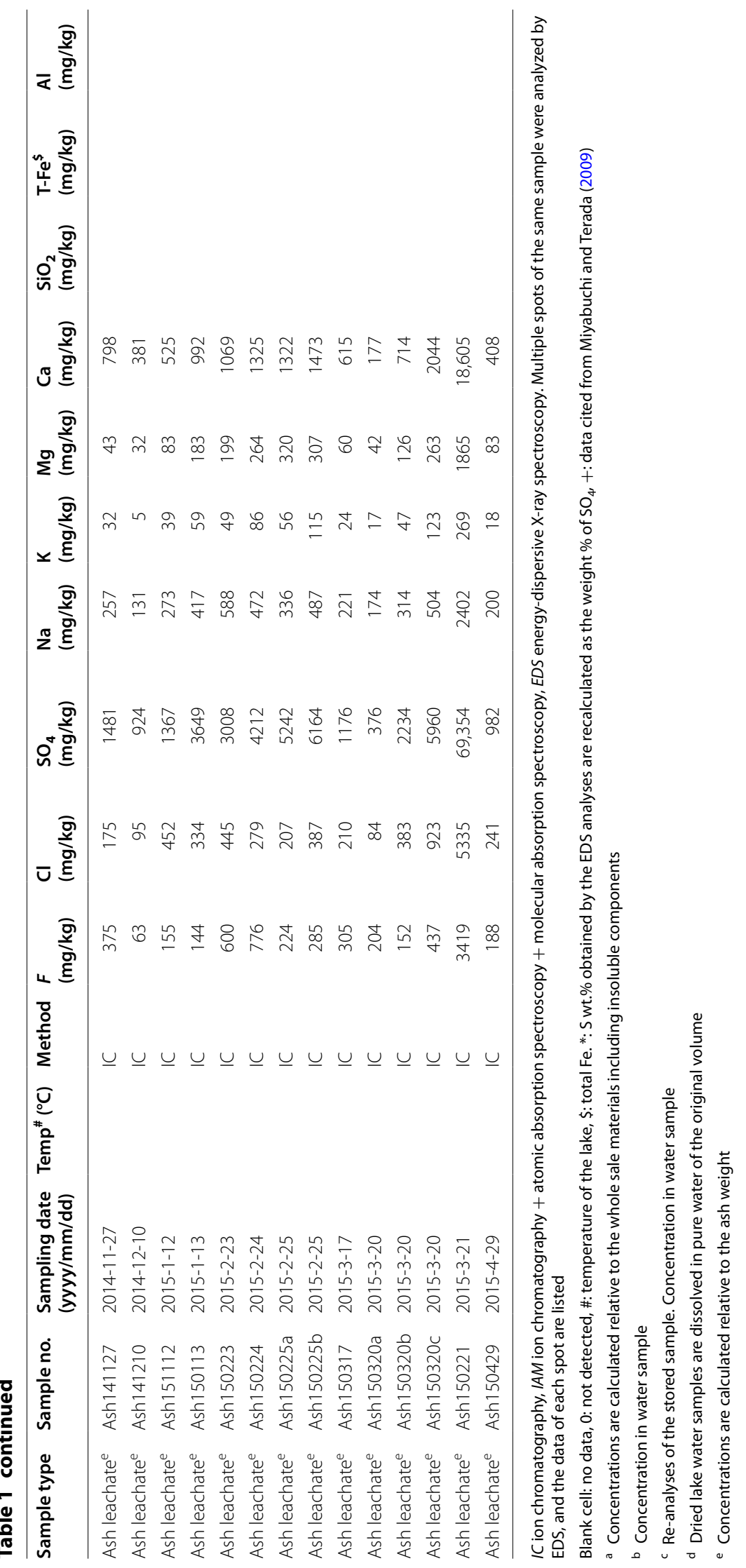



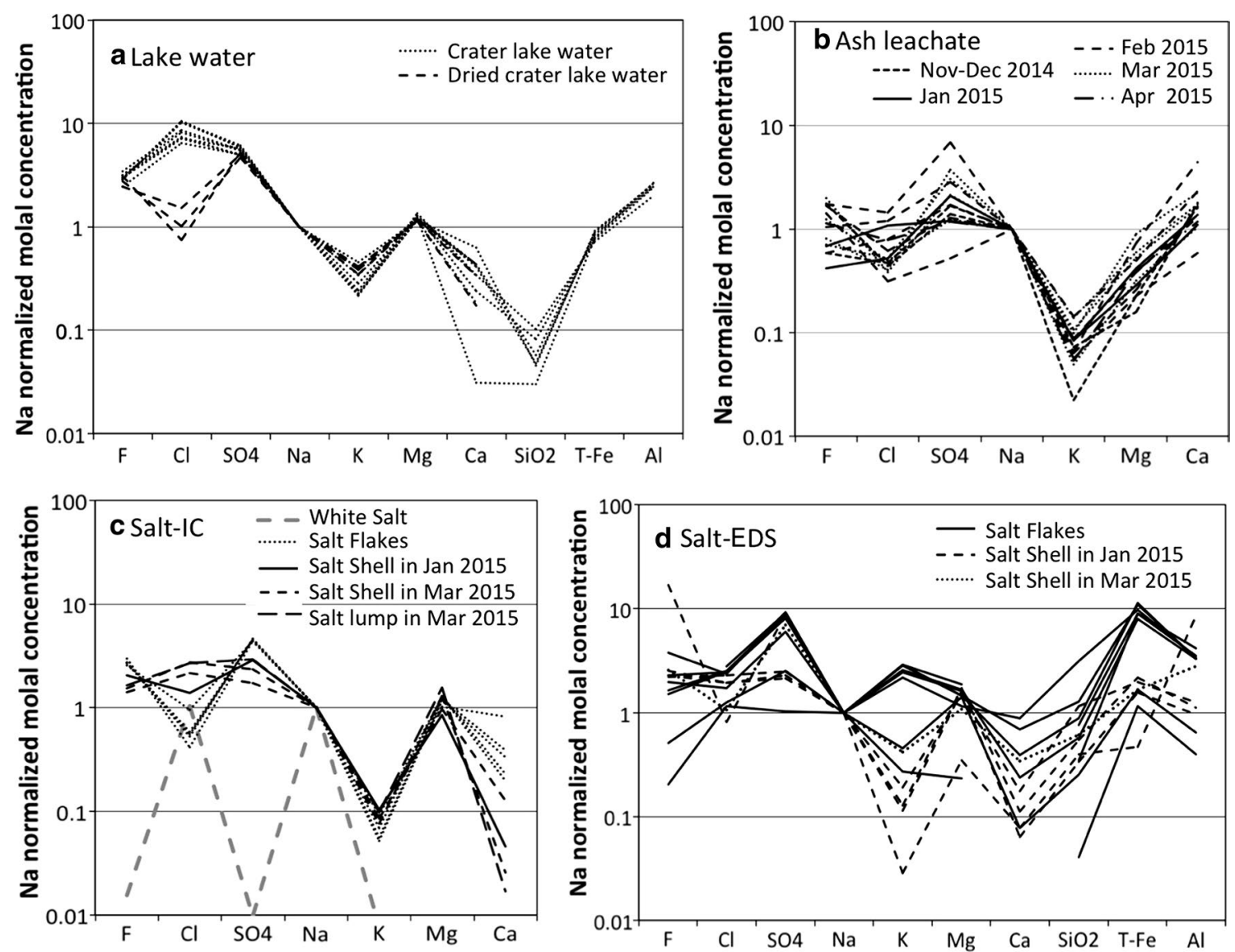

Fig. 2 Composition of the salt fallouts, ash leachates, crater lake waters, and dried samples of the crater lake waters (Table 1). The Na-normalized molal concentrations of each species are plotted. a Composition of the crater lake waters and of the dried samples of the crater lake waters. $\mathbf{b}$ Composition of the ash leachates. $\mathbf{c}$ Composition of the salt fallouts obtained by an ion chromatography analysis. $\mathbf{d}$ Composition of the salt fallouts obtained by an EDS analysis

caused by the evaporation of the lake water. The salt fallouts have large $\mathrm{Mg} / \mathrm{Na}$ ratios (close to one), similar to the ratios observed from the dried lake water samples, but different from the ash leachates. Although there are no samples of the fumarolic sublimates at Aso volcano, such sublimates rarely contain Mg-containing salts (Symonds 1993; Africano et al. 2002). The Mg-rich composition of the salt fallouts is different from the Mg-poor fumarolic sublimates.

The salt flakes were observed when a brown-colored plume emitted from a high-temperature vent, surrounded by the remnant of the crater lake (Fig. 1a). The salt flakes are likely formed by evaporation of the crater lake water sprayed from the vent, which caused the brown color observed in the plume. The compositions of the salt shells and lumps are also similar to the crater lake water, indicating that these salts were formed by evaporation of hydrothermal fluids, similar to the crater lake water. The salt shells and lumps were observed during a period when the crater lake did not exist on the surface (Fig. 1c, e). The hydrothermal fluids forming the salt shells and lumps need to be derived from an underground hydrothermal system surrounding the erupting vent (Fig. 3a).

The salt shells, particularly those from of March 2015, have the fairly specific structure of a hollow spherule with a thin shell (Fig. 1f). This structure resembles the hollow sulfur spherules floating on other crater lakes (Ohashi 1919; Takano et al. 1994). Ohashi (1919) proposed that sulfur spherules are formed by the upward passage of gas bubbles through liquid sulfur pools at the bottom of the crater lakes. By analogy, gas bubbles passing through a liquid salt pool can create the salt spherules. In contrast to the common occurrence of elemental sulfur in the fumarolic fields, massive deposits of salts are rarely observed in active volcanoes, and the salt spherule formation at a liquid salt pool is rendered less likely. 


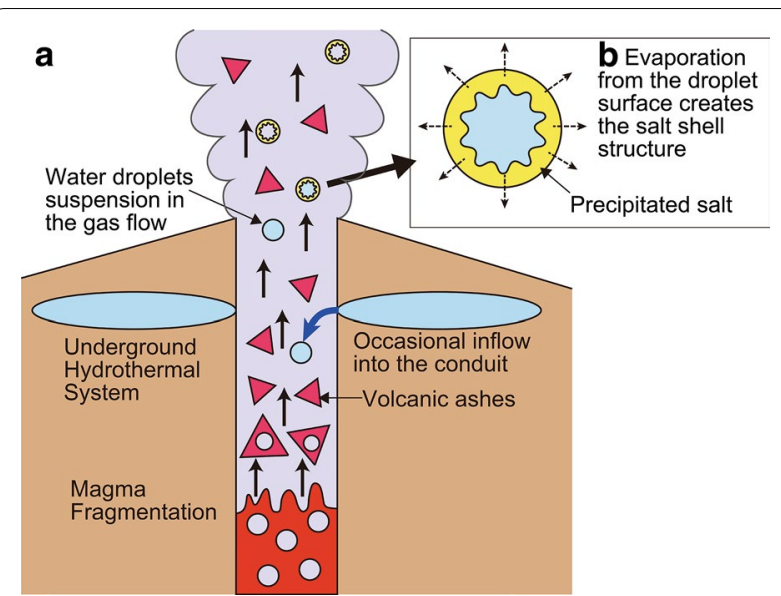

Fig. 3 A schematic diagram of the formation process of salt fallouts. a A hydrothermal solution distributed beneath the crater floor surrounding the eruption vent. The hydrothermal solution sporadically pours into the conduit of the eruption plume or the gas plume, beneath the vent. $\mathbf{b}$ The poured solution forms droplets and is then transported by the plume. Heating of the droplet in the plume evaporates the water, precipitating the salts at the droplet surface. A complete drying of the droplet creates a hollow spherical salt shell. Preservation of the fragile, hollow spherical salt shell structure during transport suggests that the salt formation occurs after magma fragmentation, implying that the hydrothermal solution layer is located at a depth shallower than the magma fragmentation level

The hollow structure of the salt shells can be formed by evaporation of droplets of hydrothermal solution during their transportation within the plume. The hydrothermal solutions pour into the plume forming droplets, which then are transported in the plume by a flow stream of gasash mixture. The droplets are heated in the plume, because plume temperature is likely much higher than that of the hydrothermal system. Heating of the droplets causes the water to evaporate and the salt to precipitate at the droplet surface, forming the salt shells, and the complete drying of the droplet makes these shells hollow (Fig. 3b). A thin shell implies that the salt volume was much smaller than the droplet volume. The crater lake water contains 8-25 wt.\% of dissolved solids (Table 1). If we assume that the densities of the crater lake water and the precipitated solids are 1.0 and $2.5\left(\mathrm{~g} / \mathrm{cm}^{3}\right)$, respectively, the precipitated salt volume is estimated to be $3.2-10 \mathrm{vol} . \%$ of the original droplet, requiring the shell thickness to be $0.01-0.03$ times the droplet radius. The estimated thickness of a shell with a $5 \mathrm{~mm}$ radius is $0.05-0.15 \mathrm{~mm}$. Although no quantitative measurements for the volume and weight ratios of the salt shells were conducted, these estimates look reasonable from the appearance (Fig. 1f). Preservation of the fragile structure of the hollow shells during the transport indicates that the salt shells were not damaged by any strong turbulent flows with ashes, and that the salt formation occurred after the magma fragmentation. A hydrothermal solution layer is likely located near the surface, at a depth shallower than the magma fragmentation level.

Formation of salt shells requires subtle conditions of hydrothermal solution flowing into a hot gas or eruption plume, but can occur at other crater lake bearing volcanoes, such as the Poás and the Copahue volcanoes. The salt fallouts, however, will not be preserved for a long time, as these will easily be crushed to a powder and get blown away or get dissolved by rain water. The salt fallouts can be observed only by frequent examinations at the crater rim on the leeward of the plume during eruptions or active degassing. Such examinations, however, can be risky. The rim of the Nakadake crater is easily accessible by road, enabling frequent exploration of the crater rim with a low risk, even during the active stages. This frequent monitoring has made the observation of rare salt fallouts possible at the Nakadake crater.

Compositions of the salt flakes collected in 2011 are almost identical to those of the dried crater lake water samples (Fig. 2). Compositions of the salt shells and lumps collected in March 2015 are similar to, but have larger $\mathrm{Cl} / \mathrm{SO}_{4}$ ratios than, the salt flakes. The salt shells and lumps have an identical composition which indicates that the salt lumps are recrystallized materials from the salt shells. The salt shells collected in January 2015 have an intermediate $\mathrm{Cl} / \mathrm{SO}_{4}$ ratio of the salts than those collected in 2011 and March 2015, suggesting a gradual increase in the $\mathrm{Cl} / \mathrm{SO}_{4}$ ratios with time. The salt shells are likely derived from the subsurface hydrothermal solutions. The temporal increase in $\mathrm{Cl} / \mathrm{SO}_{4}$ ratios can be caused by gradual changes in the hydrothermal solution composition under the subsurface conditions. However, no evidence of the composition of subsurface hydrothermal solutions currently exists, and the cause for compositional variation of the salt fallouts remains unclear.

The origin of the white salts, with an almost purely $\mathrm{NaCl}$ composition, is also unclear. The salts have a fibrous texture covering the bomb surface. Such a fibrous texture resembles that of a fumarolic sublimate precipitated from a vapor, such as fibrous sulfur. High-temperature fumarolic gases contain a relatively high concentration of $\mathrm{Na}$, approximately $10-100 \mathrm{ppm}$ at $800-900{ }^{\circ} \mathrm{C}$ (Hedenquist et al. 1994; Taran et al. 1995), which sublimates as $\mathrm{NaCl}$ by cooling. The fumarolic sublimates, however, are not pure $\mathrm{NaCl}$ but a mixture of various species depending on the sublimation temperature (Symonds 1993; Africano et al. 2002). The lack of the alteration on the bombs does not suggest a high-temperature origin for the white salts. Similar fibrous salt textures can be found also on rocks through which the seawater slowly seeps out at warm conditions (Murakami 1999). If a porous bomb contained a salt solution, a fibrous salt can form from the salt solution 
seeping out from the interior through warming by the sunshine. The NaCl-rich composition is a feature of neutral chloride waters commonly found in mature geothermal systems (Giggenbach 1996). Large $\mathrm{Na} / \mathrm{K}$ ratios can be obtained under low-temperature equilibrium conditions (Giggenbach 1988). The NaCl-rich salt can form from a mature low-temperature equilibrated hydrothermal solution. If the white salt is derived from such a neutral $\mathrm{pH}$ solution, this neutral $\mathrm{pH}$ solution would be distributed by the acidic hydrothermal system and the erupting vent, implying a heterogeneous and complex structure of the magmatic-hydrothermal interface.

\section{The difference in the ash leachate compositions com- pared to those of the salt fallouts and the crater lake water indicate that the salt components of the ashes are not derived from the hydrothermal solution, but rather from magma degassing. Several ash samples were collected on the same day of the salt shell col- lection, such as January 13, March 17, and March 20, 2015 (Table 1). Even these ash samples have larger $\mathrm{Ca} / \mathrm{Na}$ and smaller $\mathrm{Mg} / \mathrm{Na}$ ratios than the salt shells, suggesting that the contribution of the salt shell components to the ash leachate is not signifi- cant. The absence of any hydrothermal components in the ash leachate indicates that the hydrothermal solution fed into the erupting or degassing conduit was not continuous and likely infrequent.}

Instability of the magmatic-hydrothermal interface may cause phreatomagmatic eruptions (Morrissey et al. 2000). Phreatic or phreatomagmatic explosions are a common feature at the end of the eruption cycles of the Aso volcano (Sudo et al. 2006). During the continuous ash eruptions, from November 2014 to May 2015, phreatic to phreatomagmatic eruptions did not occur and the interface seemed stable. The occasional hydrothermal solution input to the degassing conduit, forming the salt fallouts, did not cause further perturbation of the interface. The southern part of the crater floor, $100 \mathrm{~m}$ wide, suddenly subsided by $50 \mathrm{~m}$ on May 3, 2015, without any significant eruptive activity. The frequency and intensity of the ash eruptions decreased thereafter, and the eruption ceased on May 21, 2015. The crater lake water subsequently recovered by June 6,2015 . The immediate recovery of the crater lake is consistent with the continuous existence of a hydrothermal system.

The lack of phreatomagmatic explosion during the recent eruption cycle (2014-2015) suggests that the magmatic-hydrothermal interface has remained stable in this case. During the eruption periods of 1984-1985 and 1989-1991, frequent phreatomagmatic explosions occurred during the late stages, followed shortly by a crater lake recovery. Ono et al. (1995) suggested that these processes can be caused by water from a heavy precipitation. However, the continuing existence of a hydrothermal system surrounding the eruptive vent provides a condition for spontaneous phreatomagmatic explosions at the Aso volcano, with possible instability at the magmatichydrothermal interface occurring even during a continuous magmatic eruption, without any heavy precipitation.

\section{Summary}

Various salt fallouts were observed during the intensive gas emission and ash eruption stages of the Nakadake crater of the Aso volcano. Chemical compositions of the salt fallouts were analyzed and compared to those of the ash leachates, the crater lake waters, and the dried samples of the crater lake water. Most of the salt fallouts have composition similar to those of the dried crater lake water samples and are quite different from those of the ash leachates. Flakes of salts were observed in May 2011 when only a small volume of the acid crater lake water remained, and a brownish plume intensively emitted from a high-temperature vent. The chemical composition indicates that the salt flakes are likely formed by the evaporation of the crater lake water sprayed by the fumarolic jet. Hollow spherical salt shells were observed at several times during the eruptive stage of 2014-2015, when the ash eruption with intermittent Strombolian explosions continued with temporal pauses. The salts are released from the plume during weak ash eruptions or shortly after the temporal cessation of the ash eruptions. Although the crater lake completely dried up prior to the eruptive stage, the similarity in chemical composition suggests that the shell salts are also formed by the evaporation of an underground hydrothermal solution pouring into the conduit of a volcanic plume. The hollow structure suggests that the salts were formed by the heating of hydrothermal solution droplets suspended in the plume stream. The preservation of the fragile hollow shell structure, even after transport by the plume, suggests that the hydrothermal solution pours into the conduit at a shallow depth well above the level of magma fragmentation. The salt shells indicate a close distribution of the hydrothermal system surrounding the erupting vent, even during the continuous magmatic eruption stage. The perturbation of the magmatic-hydrothermal interface can cause phreatomagmatic explosions, which, at this volcano, often occur at the end of an eruptive period.

Abbreviation

EDS: energy-dispersive X-ray spectrometry.

\section{Authors' contributions}

HS performed chemical analyses of salts, ash leachate, and lake waters and led the discussion. NG performed EDS analyses of the salts. AY and TO performed detailed observation of the volcanic activity including the salt fallout occurrences. AT performed collected the crater lake waters and performed their analyses. All authors contributed to discussion and preparation of the manuscript. All authors read and approved the final manuscript. 


\begin{abstract}
Author details
${ }^{1}$ Geological Survey of Japan, National Institute of Advanced Industrial Science and Technology, Central 7, 1-1-1 Higashi, Tsukuba, Ibaraki 305-8567, Japan. ${ }^{2}$ Aso Volcanological Laboratory, Kyoto University, Sakanashi, Aso, Kumamoto 869-2611, Japan. ${ }^{3}$ Volcanic Fluid Research Center, Tokyo Institute of Technology, 641-36, Kusatsu, Gunma 377-1711, Japan.
\end{abstract}

\section{Acknowledgements}

We thank Drs. T. Kagiyama, M. Utsugi, S. Yoshikawa, H. Inoue, R. Kazahaya, and Y. Miyabuchi for their supports during the fieldwork, Japan Metrological Agency for offering some of the salt fallouts samples, and Ms. M. Someya for sample analyses. We appreciate Drs. Accocela and Rouwet and an anonymous reviewer for their constructive comments, which significantly improved the manuscript.

\section{Competing interests}

The authors declare that they have no competing interests.

\section{Ethics approval and consent to participate}

Not applicable.

\section{Funding}

This work is partially supported by Grants-in-Aid for Scientific Research (KAKENHI) 22340130, 25287115, and 17H02955 from the Japan Society for the Promotion of Science (JSPS) to HS.

\section{Publisher's Note}

Springer Nature remains neutral with regard to jurisdictional claims in published maps and institutional affiliations.

Received: 1 September 2017 Accepted: 6 February 2018

Published online: 20 March 2018

\section{References}

Africano F, Van Rompaey G, Bernard A, Le Guern F (2002) Deposition of trace elements from high temperature gases of Satsuma-Iwojima volcano. Earth Planet Space 54:275-286

Capaccioni B, Rouwet D, Tassi F (2016) HCl degassing from extremely acidic crater lakes: preliminary results from experimental determinations and implications for geochemical monitoring. In: Ohba T, Capaccioni B, Caudron C (eds) Geochemistry and geophysics of active Volcanic Lakes. Geological Society, Special Publications, London. https://doi.org/10.1144/ SP437.12

Christenson BW, Reyes AG, Young R, Moebis A, Sherburn S, Cole-Baker J, Britten K (2010) Cyclic processes and factors leading to phreatic eruption events: insights from the 25 September 2007 eruption through Ruapehu Crater Lake, New Zealand. J Volcanol Geotherm Res 191:15-32

Delmelle P, Bernard A (2000) Volcanic lakes. In: Sigurdson H (ed) Encyclopedia of volcanoes. Academic Press, San Diego, pp 877-895

Giggenbach WF (1988) Geothermal solute equilibria. Derivation of Na-K-MgCa geoindicators. Geochim Cosmochim Acta 52:2749-2765

Giggenbach WF (1996) The origin and evolution of fluids in magmatic-hydrothermal systems. In: Barnes HL (ed) Geochemistry of hydrothermal ore deposits, 3rd edn. Wiley, New York, pp 737-796

Hedenquist JW, Aoki M, Shinohara H (1994) Flux of volatiles and ore-forming metals from the magmatic-hydrothermal system of Satsuma Iwojima volcano. Geology 22:585-588

Ikebe S, Watanabe I, Miyabuchi Y (2008) The sequence and style of the 19881995 eruptions of Nakadake Aso Volcano, Kyushu, Japan. Bull Volcanol Soc Japan 53:15-33 (in Japanese with English abstract)

Kawakatsu H, Kaneshima S, Matsubayashi H, Ohminato T, Sudo Y, Tsutsui T, Yamasato H, Ito H, Legrand D (2000) Aso94: Aso seismic observation with broadband instruments. J Volcanol Geotherm Res 101:129-154

Martínez A, Fernández E, Valdés J, Barboza V, Van der Laat R, Duarte E, Malavassi E, Sandoval L, Barquero J, Marino T (2000) Chemical evolution and volcanic activity of the active crater lake of Poás volcano, Costa Rica, 1993-1997. J Volcanol Geotherm Res 97:127-141
Marumoto K, Sudo Y, Nagamatsu Y (2017) Collateral variations between the concentrations of Mercury and other water soluble ions in volcanic ash samples and volcanic activity during the 2014-2016 eruptive episodes at Aso volcano, Japan. J Volcanol Geotherm Res 341:149-157

Miyabuchi Y, Terada A (2009) Subaqueous geothermal activity of acidic crater lake revealed by lacustrine sediments, Aso Volcano, Japan. J Volcanol Geotherm Res 187:140-145

Morrissey M, Zimanowski B, Wohletz K, Buettner R (2000) Phreatomagmatic fragmentation. In: Sigurdsson H (ed) The encyclopedia of volcanoes, 1st edn. Academic Press, London, pp 431-445

Murakami M (1999) Shape series of salt (NaCl) crystals (2). Bull Soc Sea Water Sci Jpn 54:260-263 (in Japanese)

Ohashi R (1919) On the peculiar sulfur spherules produced in a crater lake of the volcano Shirane, in the province of Kozuke, Central Japan. J Akita Min Coll 1:1-10

Ohsawa S, Sudo Y, Mawatari H, Shimoda G, Utsugi M, Amita K, Yoshikawa S, Yamada M, Iwakura K, Onda Y (2003) Some geochemical features of Yudamari Crater Lake, Aso volcano, Japan. Geotherm Res Rep Kyushu Univ 12:62-65 (in Japanese with English abstract)

Ohsawa S, Saito T, Yoshikawa S, Mawatari H, Yamada M, Amita K, Takamatsu N, Sudo Y, Kagiyama T (2010) Color change of lake water at the active crater lake of Aso volcano, Yudamari, Japan: Is it in response to change in water quality induced by volcanic activity? Limnology 11:207-215

Ono K, Watanabe K (1985) Geological map of Aso Volcano 1:50,000. Geological Map of Volcanoes 4. Geol Surv Japan (in Japanese with English abstract)

Ono K, Watanabe K, Hoshizumi H, Ikebe S (1995) Ash eruption of the Nakadake crater, Aso volcano, southwestern Japan. J Volcanol Geotherm Res 66:137-148

Oppenheimer C, Stevenson D (1989) Liquid sulfur lakes at Poás Volcano. Nature 342:790-793

Pasternack GB, Varekamp JC (1997) Volcanic lake systematics I. Physical constraints. Bull Volcnol 58:528-538

Rouwet D, Morrissey MM (2015) Mechanisms of Crater Lake Breaching eruptions. In: Rouwet D, Christenson B, Tassi F, Vandemeulebrouck J (eds) Volcanic Lakes. Springer, Berlin. https://doi. org/10.1007/978-3-642-36833-2_3

Rouwet D, Tassi F, Mora-Amador R, Sandri L, Chiarini V (2014) Past, present and future of volcanic lake monitoring. J Volcnol Geotherm Res 272:78-97

Shinohara H, Yoshikawa S, Miyabuchi Y (2015) In: Rouwet D, Christenson B, Tassi F, Vandemeulebrouck J (eds) Volcanic lakes. Springer, Berlin. https:// doi.org/10.1007/978-3-642-36833-2_8

Sudo Y, Tsutsui T, Nakaboh M, Yoshikawa M, Yoshikawa S, Inoue H (2006) Ground deformation and magma reservoir at Aso Volcano: location of deflation source derived from long-term geodetic surveys. Bull Volcanol Soc Japan 51:291-309 (in Japanese with English abstract)

Symonds R (1993) Scanning electron microscope observations of sublimates from Merapi Volcano, Indonesia. Geochem J 26:337-350

Takano B, Saitoh H, Takano E (1994) Geochemical implications of subaqueous molten sulfur at Yugama crater lake, Kusatsu-Shirane volcano, Japan. Geochem J 28:199-216

Takano B, Fazulullin SM, Delmelle P (2000) Analytical laboratory comparison of major and minor constituents in an active crater lake. J Volcanol Geotherm Res 97:497-508

Taran YA, Hedenquist JW, Korzhinsky MA, Tokachenkko S, Shimulovich KI (1995) Geochemistry of magmatic gases from Kudryavy volcano, Iturup, Kuril Islands. Geochim Cosmochim Acta 59:1749-1761

Terada A, Hashimoto T (2017) Variety and sustainability of volcanic lakes: response to subaqueous thermal activity predicted by a numerical model. J Geophy Res Solid Earth. https://doi.org/10.1002/2017JB014387

Terada A, Hashimoto T, Kagiyama T (2012) Water flow model of active crater lake at Aso volcano, Japan: fluctuation of magmatic gas and groundwater fluxes from underlying hydrothermal systems. Bull Volcanol 74:641-655

Varekamp JC, Pasternack GB, Rowe GL Jr (2000) Volcanic lake systematics II. Chemical constraints. J Volcanol Geotherm Res 97:161-179

Witham CS, Oppenheimer C, Horwell CJ (2005) Volcanic ash-leachates: a review and recommendation for sampling methods. J Volcanol Geotherm Res 141:299-326

Yokoo A, Miyabuchi T (2015) Eruption at the Nakadake 1st crater of Aso volcano started in November 2014. Bull Volcanol Soc Japan 60:275-278 (in Japanese) 